\section{Research Article}

(C) 2020 Ajibola et.al.. This is an open access article licensed under the Creative Commons Attribution-NonCommercial 4.o International License (https://creativecommons.org/licenses/by-nc/4.o/)

\title{
Assessing the Methods of Valuing Contaminated Land in Rivers State, Nigeria
}

\author{
M. O. Ajibola
}

\author{
A. I. Kabiamaowei \\ A. O. Oluwunmi \\ D. R. Owolabi \\ Department of Estate Management, \\ College of Science and Technology, \\ Covenant University, Ota, Nigeria
}

Doi: 10.36941/ajis-2020-0035

\begin{abstract}
The practice of environmental valuation for compensation has raised serious concerns among estate surveyors and valuers (ESVs) practicing in Nigeria due to the challenges posed by the enabling laws and other factors. This study examined the methods adopted by ESVs in carrying out the valuation of land contaminated by oil spill in Rivers State. The study focused on ESVs practicing with registered firms in Rivers State. Primary data was obtained by administration of questionnaires on 120 ESVs out of which 80 questionnaires were retrieved and used for the analysis. Also, semi-structured interviews were conducted with estate surveyors and valuers identified to be experienced in the subject of study in order to obtain data on their practice and experience. The primary data was analysed using, percentages, relative importance index (RII) and principal component analysis as well as coding and narrating for the interviews. The findings indicated that the methods adopted for valuation are the income capitalization, predetermined compensation rate, sales comparison, market prices and depreciated replacement cost approach. The study therefore recommends that professional bodies should continuously train and develop ESVs in this aspect of valuation.
\end{abstract}

Keywords: Compensation, Contaminated Land, Environmental Valuation, Niger Delta, Nigeria

\section{Introduction}

Compensation for expropriated land in Nigeria has brought into the front burner the need to include the constituents of environmental resources in the valuation assignments. Governments, both at the federal, state and local levels require land for the various projects to serve their various communities hence the need for land acquisition and payment of compensation. On the other hand, when land is contaminated, especially by oil spills, as in the case of the study area, a lot of environmental resources are affected. Whenever land is contaminated, the effects are not just on land and buildings, it goes to affecting the environmental resources in the affected communities. There are diverse methods that could be used in the valuation of land and buildings, plant, machinery and equipment, furniture, 
fixtures and fittings but these would not suffice in assessing the effects on environmental resources. This in turn has placed high demand on ascertaining the appropriate methods and techniques that could be adopted in the determination of the monetary worth of such land.

\section{Literature Review}

Ajibola, Oluwunmi, Kabiamaowei, Owolabi and Akinwale (2019) were of the view that man's continuous existence is hinged on the goods and services provided by the natural environment. Since these natural goods and services are not traded in the open markets they are therefore regarded as having no marketplace prices. However, their values still need to be assessed especially when there is need to compensate the affected persons. They stated further that the ability for future economic growth and development itself is being threatened by environmental degradation, especially land contamination by oil spills as prevalent in the study area.

In order to determine the value of an interest in a property, there are various techniques available to the Valuer to carry out the exercise. However, the techniques adopted are determined by factors such as the type of property, available data and basis of valuation amongst others. A study on Australian Valuers by Chan (200o) revealed that there are two fundamental ways to assess polluted properties. First, the impaired/affected valuation technique involves the appraiser assessing the land as though it were uncontaminated. The impaired/affected valuation technique necessitates that the valuer takes the impaired state of the property into consideration. The second technique requires that the property should first be assessed as though it were uncontaminated and then provisions are made to account for whatever loss in income caused by the impairment, and any other loss incurred to carry out investigations plus the cost of remediation as well as impact of stigma. The author expressed the method with the equation given below:

$\mathrm{VC}=\mathrm{VU}-\mathrm{L}-\mathrm{CR}-\mathrm{S}$

Where $\mathrm{VC}=$ contaminated value

$\mathrm{VU}=$ uncontaminated value

$\mathrm{L}=$ Loss due to reduced income/productivity and/or legal liabilities

$\mathrm{CR}=$ investigation and remediation costs

$\mathrm{S}=$ stigma impacts

The study revealed that the valuation methods used by the Valuers in practice are the comparison method, the capitalization method, the cost method and the hypothetical development method. However, he noted that adopting the traditional methods of valuation has its challenges since they rely greatly on market data. For example, lack of transaction data on contaminated properties, difficulty in obtaining comparables since environmental problems are as unique as fingerprints. The author therefore concluded by saying that the Australian Valuers are mainly adopting the conventional methods of valuation in assessing the value of contaminated land, the methods that allow for more innovation are hardly ever used. Oni, Ajibola, Iroham, and Akinjare (2015) were of the opinion that since the desire of the affected farmers is to be adequately compensated, the valuation methods adopted should take cognisance of the aspect of the environment that are not traded in the market.

In the case of contaminated land valuation in the United States, Thomas (2003) made reference to the Advisory Opinion 9 (AO-9) and the Uniform Standards of Professional Appraisal Practice (USPAP). The author admonished that prior to assessing contaminated properties which require specialized methods and techniques, the appraisers ought to be abreast with and correctly adopt those recognized techniques that will enhance and necessitate the production of a credible appraisal. Further, the appraiser's expertise and competence in applying these techniques is a requirement in this field of practice; it is also necessary to utilize methods that have gained general acceptance since most contaminated land valuations are for litigation. The study revealed that the income capitalization analysis is most widely adopted by appraisers for valuing contaminated land; however, access to market information is very essential in order to adopt this method. 
The Valuer General's Policy, Sydney (2017) provides a guide on the methods to use and factors to consider when valuing contaminated land for rating and taxing purposes. The methods provided are the direct comparison method which involves comparing market sales with the subject property and the hypothetical development method usually adopted when there is not sufficient data on direct comparable sales.

Contaminated land in the above countries deals with contamination caused by oil spill and other heavy industrial activities, not just contamination by oil spill which is the focus of this study. Also, the contaminated properties dealt with in those countries are mostly in urban settings unlike the rural and remote settings found in Rivers State and the Niger Delta region in Nigeria. In contrast to the rural setting, contamination valuation in urban and developed nations may be a lot easier due to the availability of comparables and relevant data. Consequently, this study reviewed Nigerian based cases.

In Nigeria, valuation for compensation for compulsory acquisition or oil spill is a statutory valuation whose basis and methods are guided by laws. In the case of compulsory acquisition, the method stipulated by the Land Use Act of 1978 is the Replacement Cost approach. With regards to land contaminated by oil spill, Babawale (2013) asserted that a common method adopted while valuing environmentally impaired properties is the Before and After approach which was also prescribed in the Oil Pipelines Act (Cap. 07 LFN, 2004) Section 20(3). Generally, the process as presented involves valuing the property in its unimpaired state; then, assess it in its impaired state taking cognizance of all costs and risk/stigma effects. The difference between the two figures gives the loss in value as shown below:

i. An estimation of the worth of the property under a hypothetical state as though it did not suffer any loss caused by environmental damage (the unimpaired value);

ii. An assessment of the property taking cognizance of the environmental damage (the impaired value):

Impaired value $=$ Unimpaired value - Cost effects (remediation and related costs) - use effects (effects on site usability) - Risk effects (environmental risk/stigma);

iii. Calculate the difference between the two estimates which will produce the loss in value due to the impairment.

That is: Property value diminution = Unimpaired value - Impaired value.

Likewise,

Property value diminution $=$ Cost effects $($ remediation and related costs $)+$ Use effects (effects on site usability) + risk effects (environmental risk/stigma).

Without doubt, this technique requires expert contribution from scientists in the field such as micro biologists, marine scientists, environmental scientists, medical and health experts, to mention just a few. But his opinion was that most valuation reports rarely made reference to any input from these scientific experts.

In practice, what is obtainable were examined by Ajibola, Peter, Babajide and Oni (2013), Akujuru (2014) and Akujuru and Ruddock (2014). For instance, Akujuru and Ruddock (2014) ${ }^{4}$ provided a framework for the inclusion of socio-cultural values in assessing contaminated land. They posited that the pollution of the environment damages economic, ecological and socio-cultural values that make up the total economic value (TEV) of the polluted property when combined together. They explained that appraisers tend to rely on the normative valuation techniques while assessing environmental contamination, but these models do not produce adequate values that recognise the uniqueness of Niger Delta ecosystem. Their conclusion was that, while the contingent survey method is prone to weaknesses, it provides the greatest possibility to incorporate the cultural and other intangible values lost due to contamination.

The applicable approaches suggested by Akujuru (2014) indicated that the income capitalization approach and the impaired approach are appropriate for valuing contaminated properties; especially, the author's expression which expanded the various items and costs; making it understandable and applicable. According to Oluwunmi, Akinjare, Ajibola and Oloke (2018), man's greatest desire is to 
live in a clean and decent environment hence efforts should be made to compensate him for any impairment of his environment. From their submission, it is imperative that proper assessment fo compensation should be carried. This will require the adoption of methods that capture the value of environmental resources. This study therefore set out to unearth the methods of valuing land contaminated by oil spills in Rivers State, Nigeria with a view to guiding practicing Estate Surveyors and Valuers in the study area, in particular, and Nigeria in general in adopting the appropriate method for the assessment of environmental resources/impacts.

\section{Methodology}

In Nigeria, the Estate Surveyor and Valuer (ESV) is the only professional empowered by law to determine the value of land and landed property and also has the requisite training to carry out valuation for contaminated land. In the study area, there are a number ESVs working in either public institutions or private estate firms. However, for the purpose of this study, the ESVs in real estate firms in Rivers State constituted the study population. The Nigerian Institution of Estate Surveyors and Valuers' (NIESV) directory of 2016 revealed that Rivers State has sixty six (66) registered firms; however, the information obtained from the State Branch indicates that there are one hundred and twenty (120) registered firms in the State. This disparity may be as a result of new firms registered after the Directory has been published. For this study, the non- random purposeful sampling was done to obtain the required data from the Valuers deemed to have acquired the knowledge and experience for the study. The study sampled 120 Valuers in estate firms in the study area and $67 \%$ response rate was achieved.

In addition, six Valuers deemed to be more experienced and knowledgeable in contaminated land valuation were also contacted for semi-structured interviews. The Statistical Packages for Social Sciences (SPSS) tools adopted for analysis include the relative importance index (RII) and principal component analysis (PCA). On the other hand, the data retrieved from semi-structured interviews was analyzed by identifying and narrating the main themes. Presentation of data for the interview section was done after the questionnaire analysis for each theme. This approach was adopted to narrate and describe how Valuers carry out valuation for land contaminated by oil spill as perceived and experienced from the perspective of those interviewed.

\section{Results and Discussion}

The study was conducted to identify the methods adopted by valuers when carrying out the valuation of contaminated land, especially in the oil rich Niger Delta. The study mainly focused on Rivers State, being the administrative centre of South-South geopolitical zone of Nigeria. The core respondents are the Estate Surveyors and Valuers working in real estate firms in the study area. One ESV was proxy for each of the 120 firms. The data collected was collated, analysed and presented in Tables $1-6$.

Table 1: Involvement in Assessment of Land Contaminated by Oil Spill

\begin{tabular}{ccc}
\hline Response & Frequency & Percentage \\
\hline Yes & 71 & 88.8 \\
No & 9 & 11.2 \\
\hline
\end{tabular}

The analysis contained in Table 1 shows that $88.8 \%$ of the respondents have at one time or the other participated in the valuation of land contaminated by oil spill. This scenario is not unexpected since most of the locations in the Niger Delta suffer from contamination whenever there is an incidence of oil spill culminating to land pollution that will require valuation to ascertain the sum/amount to be paid as compensation for damages suffered by the oil spill victims. 
Table 2: Number of Times Involved

\begin{tabular}{ccc}
\hline Times of Involvement & Frequency & Percentage \\
\hline $1-5$ & 45 & 63.5 \\
$6-10$ & 11 & 15.5 \\
$11-15$ & 9 & 12.7 \\
$16-20$ & 3 & 4.2 \\
Above 21 & 3 & 4.2 \\
\hline
\end{tabular}

The number of times the respondent firms had been involved is analysed and shown in Table 2. It could be seen from the table that $63.5 \%$ of the firms had been involved in this type of assignment between 1 and 5 times. This was followed by the group of firms (15.5\%) that had participated in the assignment in not less than 6 times. Other categories are: $11-15$ times (12.7\%), $16-20$ times (4.2\%) and more than 21 times (4.2\%). The table revealed that Valuers have participated in the valuation of damaged properties due to oil spill either just for a few times or on several occasions. $79 \%$ of the respondents have participated for about 1 - 10 times. This might be connected with the fact that most times compensations are usually determined without recourse to the appropriate professionals in practice.

Table 3: Rating the Frequency of Using Valuation Methods

\begin{tabular}{|c|c|c|c|c|c|c|c|}
\hline Method & $\begin{array}{l}\text { Never } \\
\text { Used }\end{array}$ & $\begin{array}{l}\text { Rarely } \\
\text { Used }\end{array}$ & $\begin{array}{c}\text { Used } \\
\text { Occasionally }\end{array}$ & $\begin{array}{l}\text { Frequently } \\
\text { Used }\end{array}$ & $\begin{array}{c}\text { Always } \\
\text { Used }\end{array}$ & RII & Ranking \\
\hline Sales Comparable Method & $3(3)$ & $9(18)$ & $18(54)$ & $29(116)$ & $12(60)$ & 0.7070 & 3 \\
\hline Income Capitalisation Method & $2(2)$ & $7(14)$ & $12(36)$ & $32(128)$ & $18(90)$ & 0.7662 & 1 \\
\hline Depreciated Replacement Cost Method & $11(11)$ & $7(14)$ & $5(15)$ & $39(156)$ & $9(45)$ & 0.6789 & 5 \\
\hline Residual Method & 18(18) & $38(76)$ & $15(45)$ & $o(0)$ & $o(0)$ & 0.3915 & 10 \\
\hline Profits and Accounts Method & $33(33)$ & $24(48)$ & $8(24)$ & $6(24)$ & $o(0)$ & 0.3634 & 13 \\
\hline Pre-determined Compensation Rates & $8(8)$ & $7(14)$ & $9(27)$ & $31(124)$ & $16(80)$ & 0.7127 & 2 \\
\hline Discounted Cashflow Technique & 34(34) & 17(34) & $10(30)$ & $10(40)$ & $o(0)$ & 0.3887 & 11 \\
\hline Productivity Function & 29(29) & $21(42)$ & $15(45)$ & $6(24)$ & $\mathrm{o}(\mathrm{o})$ & 0.3944 & 9 \\
\hline Participatory Approach & $43(43)$ & $13(26)$ & 3(9) & $6(24)$ & $6(30)$ & 0.3718 & 12 \\
\hline Market Prices & $6(6)$ & $14(28)$ & $8(24)$ & $25(100)$ & 18(90) & 0.6986 & 4 \\
\hline Contingent Valuation Method & 29(29) & $18(36)$ & $16(48)$ & $8(32)$ & $o(0)$ & 0.4084 & 7 \\
\hline Travel Cost Techniques & $40(40)$ & $20(40)$ & $10(30)$ & $1(4)$ & $o(0)$ & 0.3211 & 14 \\
\hline Hedonic Pricing & $29(29)$ & $19(38)$ & $14(42)$ & $9(36)$ & $\mathrm{o}(\mathrm{o})$ & 0.4084 & 7 \\
\hline Benefit Transfer Technique & $45(45)$ & $14(28)$ & $12(36)$ & $\mathrm{o}(\mathrm{o})$ & $\mathrm{o}(\mathrm{o})$ & 0.3070 & 15 \\
\hline Cost-Benefit Analysis (Trade-Off Analysis) & $21(21)$ & $14(28)$ & $25(75)$ & $5(20)$ & $6(30)$ & 0.4901 & 6 \\
\hline
\end{tabular}

The RII and ranking of the frequency of using valuation methods is as illustrated in Table 3. Income capitalisation method, with RII of 0.7662 was ranked as the most frequently applied method of valuing land contamination due to oil spills in the study area. This was followed by the use of predetermined compensation rates $(\mathrm{RII}=0.7172)$. Coming in the $3^{\text {rd }}, 4^{\text {th }}, 5^{\text {th }}$ ranking respectively are sales comparable method $(\mathrm{RII}=0.7070)$, market prices $(\mathrm{RII}=0.6986)$, and depreciated replacement cost method (RII = 0.6789). The methods predominantly used are ranked $1-5$ in Table 3; which could be due to their reliance on market data which is easier to come by than the application of those methods of valuing environmental resources (participatory approach, $\mathrm{RII}=0.3718$; travel cost techniques, $\mathrm{RII}=$ 0.3211 and benefit transfer technique, $\mathrm{RII}=0.3070$ ) that are rarely traded in the open market, they are ranked $13^{\text {th }}, 14^{\text {th }}, 15^{\text {th }}$ and $16^{\text {th }}$ respectively. Also, the methods (ranked $1-5$ ) were adopted possibly because of the peculiar nature of the environment, the data available and the laws guiding statutory valuations in Nigeria.

The analysis from the interviews revealed that income capitalization method is appropriate for such valuations, but due to the constraints of the statutes, Valuers adopt other methods like the cost 
approach and the use of pre-determined rates which are deemed to be grossly inadequate. The findings from this interview support the work of Akujuru, (2014) ${ }^{3}$ and Kakulu (2014) ${ }^{7}$.

Based on the result, it could be inferred that in practice, valuers adopt the income capitalization method which they deemed most appropriate but also adopt the depreciated replacement cost method and the pre-determined rates because of the provisions of the law and the ease of computation/application.

A further check was conducted on the valuation methods used for assessing land contamination due to oil spill. Principal component analysis (PCA) a variant of factor analysis was used to reduce the factors or components (methods) to the most important or the underlying variables (methods). This approach helps in identifying the variables that require the concentration of the research work. The results of these are contained in Tables $4-6$.

Table 4: Communalities

\begin{tabular}{lcc}
\hline Method & Initial & Extraction \\
\hline Sales Comparable Method & 1.000 & .553 \\
Income Capitalisation Method & 1.000 & .790 \\
Depreciated Replacement Cost Method & 1.000 & .618 \\
Residual Method & 1.000 & .719 \\
Profits and Accounts Method & 1.000 & .823 \\
Pre-determined Compensation Rates & 1.000 & .877 \\
Discounted Cashflow Technique & 1.000 & .829 \\
Productivity Function & 1.000 & .711 \\
Land Value Extraction & 1.000 & .760 \\
Participatory Approach & 1.000 & .843 \\
Market Prices & 1.000 & .858 \\
Contingent Valuation Technique & 1.000 & .885 \\
Travel Cost Method & 1.000 & .851 \\
Hedonic Pricing & 1.000 & .844 \\
Benefit Transfer Technique & 1.000 & .781 \\
Cost-Benefit Analysis (Trade-Off Analysis) & 1.000 & .778 \\
\hline
\end{tabular}

Extraction Method: Principal Component Analysis.

Table 4 shows that communalities are computed so as to determine the extent to which a variable is explained by the components. They are the outcome of the mathematical sum of all the squared factor loadings for each variable. The table indicates the communality values are more than 0.5 hence, they are considered adequate for further analysis. Any variable below this benchmark is usually removed from further consideration. It therefore means that the variables with communalities less than 0.5 would have been accounted for by the extracted factors. It could be seen from Table 4 that all the components (factors) had communalities greater than 0.5 and therefore considered for further analysis. 
Table 5: Total Variance Explained

\begin{tabular}{|c|c|c|c|c|c|c|c|c|c|}
\hline \multirow[t]{2}{*}{ Component } & \multicolumn{3}{|c|}{$\begin{array}{c}\text { Initial } \\
\text { Eigenvalues }\end{array}$} & \multicolumn{3}{|c|}{$\begin{array}{l}\text { Extraction Sums of } \\
\text { Squared Loadings }\end{array}$} & \multicolumn{3}{|c|}{$\begin{array}{l}\text { Rotation Sums of } \\
\text { Squared Loadings }\end{array}$} \\
\hline & Total & $\begin{array}{c}\% \text { of } \\
\text { Variance }\end{array}$ & $\begin{array}{c}\text { Cumulative } \\
\%\end{array}$ & Total & $\begin{array}{c}\% \text { of } \\
\text { Variance }\end{array}$ & $\begin{array}{c}\text { Cumulative } \\
\%\end{array}$ & Total & $\begin{array}{c}\% \text { of } \\
\text { Variance }\end{array}$ & $\begin{array}{c}\text { Cumulative } \\
\%\end{array}$ \\
\hline 1 & 4.682 & 29.262 & 29.262 & 4.682 & 29.262 & 29.262 & 3.050 & 19.065 & 19.065 \\
\hline 2 & 2.170 & 13.560 & 42.822 & 2.170 & 13.560 & 42.822 & 2.930 & 18.312 & $37 \cdot 378$ \\
\hline 3 & 2.015 & 12.596 & 55.418 & 2.015 & 12.596 & 55.418 & 2.200 & 13.751 & 51.128 \\
\hline 4 & 1.279 & 7.992 & 63.409 & 1.279 & 7.992 & 63.409 & 1.669 & 10.429 & 61.557 \\
\hline 5 & 1.203 & 7.518 & 70.928 & 1.203 & 7.518 & 70.928 & 1.341 & 8.381 & 69.938 \\
\hline 6 & 1.173 & 7.334 & 78.262 & 1.173 & $7 \cdot 334$ & 78.262 & 1.332 & 8.323 & 78.262 \\
\hline 7 & .737 & 4.608 & 82.870 & & & & & & \\
\hline 8 & .697 & 4.358 & 87.228 & & & & & & \\
\hline 9 & .523 & 3.267 & 90.495 & & & & & & \\
\hline 10 & .416 & 2.600 & 93.095 & & & & & & \\
\hline 11 & .302 & 1.889 & 94.984 & & & & & & \\
\hline 12 & .262 & 1.635 & 96.619 & & & & & & \\
\hline 13 & .237 & 1.483 & 98.102 & & & & & & \\
\hline 14 & .140 & .876 & 98.978 & & & & & & \\
\hline 15 & .101 & .631 & 99.609 & & & & & & \\
\hline 16 & .062 & .391 & 100.000 & & & & & & \\
\hline
\end{tabular}

Extraction Method: Principal Component Analysis.

As contained in Table 5, the eigenvalue table is categorised into Initial eigenvalues, Extracted Sums of Squared Loadings and Rotation of Sums of Squared Loadings. The table described the total explained variance of the components together with the eigenvalues of each of the factors. It was clear from the table that all the factors (components) with eigenvalues greater than 1.0 were extracted and this shows six factors (income capitalisation method, pre-determined compensation rates, sales comparable method, market prices, depreciated replacement cost method and cost-benefit analysis (Trade-Off Analysis). They are the underlying methods adopted in carrying out the valuation of land contaminated by oil spills, in the study area. It could further be gleaned from Table 5 that the first factor accounted for $\mathbf{2 9 . 2 6 \%}$ while the second, third, fourth, fifth and sixth factors accounted for $13.56 \%, 12.59 \%, 7.9 \%, 7.51 \%$ and $7.33 \%$ respectively. In summary, the six components accounted for $78.26 \%$ of the total variance. Therefore, the conclusion from the table is that with the six factors, it is possible to predict $78.26 \%$ of the information in all the sixteen variables hence, the remaining ten components that accounted for $\mathbf{2 1 . 7 4 \%}$ are not significant methods adopted in valuing land.

Table 6: Component Matrix

\begin{tabular}{lcccccc}
\hline & \multicolumn{7}{c}{ Component } \\
\hline Sales Comparable Method & $\mathbf{1}$ & $\mathbf{2}$ & $\mathbf{3}$ & $\mathbf{4}$ & $\mathbf{5}$ & $\mathbf{6}$ \\
Income Capitalisation Method & .568 & -.142 & .252 & .066 & .202 & .319 \\
Depreciated Replacement Cost Method & .598 & .026 & -.460 & -.052 & -.135 & .446 \\
Residual Method & .486 & .095 & .561 & -.015 & .241 & -.018 \\
Profits and Accounts Method & .657 & -.210 & -.382 & -.141 & .219 & .171 \\
Pre-determined Compensation Rates & .455 & -.308 & -.167 & .639 & -.083 & .279 \\
\hline
\end{tabular}




\begin{tabular}{lcccccc}
\hline & \multicolumn{7}{c}{ Component } \\
\hline & $\mathbf{1}$ & $\mathbf{2}$ & $\mathbf{3}$ & $\mathbf{4}$ & $\mathbf{5}$ & $\mathbf{6}$ \\
\hline Discounted Cashflow Technique & .717 & -.068 & -.179 & -.073 & -.483 & -.197 \\
Productivity Function & -.049 & .672 & -.334 & .178 & -.155 & .299 \\
Land Value Extraction & .593 & -.077 & .604 & -.187 & .049 & -.034 \\
Participatory Approach & -.105 & .281 & .545 & .612 & -.232 & .167 \\
Market Prices & .614 & -.083 & .585 & -.133 & -.301 & .151 \\
Contingent Valuation Technique & .518 & .770 & .048 & -.093 & -.091 & -.067 \\
Travel Cost Method & -.121 & .879 & .025 & .042 & .220 & -.114 \\
Hedonic Pricing & .849 & .197 & -.247 & -.005 & -.080 & -.133 \\
Benefit Transfer Technique & .376 & -.013 & -.085 & .338 & .719 & -.031 \\
Cost-Benefit Analysis (Trade-Off Analysis) & .791 & .132 & -.130 & -.129 & .163 & -.274 \\
\hline
\end{tabular}

Extraction Method: Principal Component Analysis.

a. 6 components extracted.

Table 6 contains the component matrix of the methods adopted in valuing land contaminated by oil spills. Using the table, components with factor loadings greater than 0.5 were considered ideal for this study and this shows that component 1 is strongly correlated with hedonic pricing (o.849), cost-benefit analysis /trade-off analysis (0.791) and discounted cashflow technique (0.717) while it is least correlated with productivity function (-0.049) and participatory approach (-0.105). The second component is strongly correlated with travel cost techniques (o.879), contingent valuation method (o.770) and productivity function $(0.672)$ but poorly correlated with income capitalisation method (-0.026) and benefit transfer technique (-0.013). The third component correlates with land value extraction (0.604) market prices (0.585), depreciated replacement cost method (0.561) and participatory approach (0.545). The fourth component stoutly correlates with profits or accounts method (0.639) and participatory approach (o.612). While the fifth component mostly correlates with benefit transfer technique (0.719) the sixth component did not correlate with any of the variables.

\section{Conclusion and Recommendations}

This study examined the methods adopted by valuers while assessing oil spill contaminated land in the study area. It was discovered that various methods were adopted when valuing land contaminated by oil spill. In the event that a company is liable to pay compensation and the ESV is contacted, he is required professionally to adopt measures that ensure fair and credible opinion of value.

With regards to the methods adopted for the valuation of oil spill contaminated land, the study revealed that Valuers are using five methods in practice namely: the income capitalization method, pre-determined compensation rates, sales comparable method, market prices and the Depreciated Replacement Cost methods. The result showed that most frequently used are the income capitalization approach and the pre-determined rates. The opinion of Valuers is that, the former is appropriate which conforms with some local and international studies. The major concern is the use of the pre-determined rates which are considered not to be economically derived and therefore can never produce adequate and fair compensable values.

Following from the conclusion, the study therefore recommends that Estate Surveyors and Valuers should be trained at all levels on environmental valuation. This means that the school curricular can be upgraded to equip graduates better on the subject and the Nigerian Institution of Estate Surveyors and Valuers (NIESV) and Estate Surveyors and Valuers Registration Board of Nigeria (ESVARBON) are to also ensure continuous training of Valuers in this area of practice. This will equip ESVs better on the methods of valuation meant for assessing oil spill contaminated land and also reduce the challenges that estate surveyors and Valuers are confronted with when carrying out this type of assignment. 


\section{References}

Ajibola, M. O., Peter, N. J., Babajide, O. S., and Oni, A. O. (2014). An Examination of the Basis and Methods of Wetland Valuation for Compensation in the Niger Delta, Nigeria. Covenant Journal of Research in the Built Environment (CJRBE), 1(2), 1-27.

Ajibola, M. O., Oluwunmi, A. O., Kabiamaowei, A. I., Owolabi, D. R. and Akinwale, O. M. (2019) Green Economy: The Role of Estate Surveyors and Valuer. A paper presented at the $3^{\text {rd }}$ International Conference on Science and Sustainable Development (ICSSD 2019), at Centre for Research, Innovation and Discovery, Covenant University, Ota. Ogun State. May 6 - 8 2019. IOP Conf. Series: Journal of Physics: Conf. Series 1299 (2019) o12017 IOP Publishingdoi:10.1088/1742- 6596/1299/1/012017

Akujuru, V. (2014). A framework for determining the Compensable Value of Damages due to Contamination to Wetlands in the Niger Delta of Nigeria. A Thesis submitted in partial fulfilment of the requirements for the award of the Degree of Doctor of Philosophy of the University of Salford, School of the Built Environment.

Akujuru, V., and Ruddock, L. (2014). Incorporation of Socio-Cultural Values in Damage Assessment Valuations of Contaminated Lands in the Niger Delta. Land, 3(3), 675-692.

Babawale, G. K. (2013). Emerging Issues in Compensation Valuation for Oil Spillage in the Niger Delta Area of Nigeria. Journal of Reviews on Global Economics, 2(2), $31-45$.

Chan N. (2000) How Australian Valuers Value Contaminated Land. Pacific Rim Real Estate Society (PRRES) Conference 2000, Sydney.

Kakulu, I. I. (2014). Post Impact Environmental Assessment Survey and Contaminated Land Valuation for Compensation in Nigeria.Journal of Nigerian Environmental Society. (2), 31-41.

Oluwunmi, A. O., Akinjare, O. A., Ajibola, M. O., Oloke, O. C., (2018) An Evaluation of the Basic Facility Needs of Private University Students in Ogun State, Nigeria. International Journal of Civil Engineering and Technology, 9(9) pp. $476-484$

Oni, A. O., Ajibola, M. O., Iroham, O. C. and Akinjare, O. A. (2015) Analysis of Accessibility Impact on Commercial Property Values in Ikeja, Nigeria. Proceedings of the $25^{\text {th }}$ International Business Information Management Association Conference - Innovation Vision 2020: Form Regional Development Sustainability to GlobalEconomic Growth, IBIMA

Thomas O. J. (2003) Methods and Techniques for Contaminated Property Valuation. The Environment and the Appraiser. The Appraisal Journal, $311-320$.

Valuer General's Policy (2017) Valuation of Contaminated Land. Office of the Valuer General, Sydney 2000. 